\title{
Antioxidant and antineurodegenerative properties of St. John's-wort dry extract
}

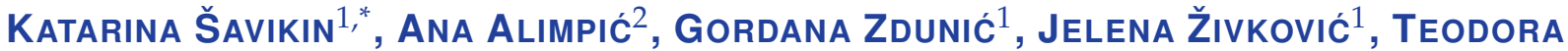 \\ Janković ${ }^{1}$, NebojŠa MenKović ${ }^{1}$, And Sonja Duletić-LaušeVIĆ ${ }^{2}$ \\ ${ }^{1}$ Institute for Medicinal Plant Research "Dr. Josif Pančić", Tadeuša Košćuška 1, 11000 Belgrade, Serbia \\ ${ }^{2}$ University of Belgrade, Faculty of Biology, Institute of Botany and Botanical Garden "Jevremovac", Takovska 43, 11000 Belgrade, Serbia \\ *Corresponding author: ksavikin@mocbilja.rs
}

Received: September 21, 2017

Accepted: September 28, 2017

Published on-line: September 29, 2017

Published: December 25, 2017

\begin{abstract}
Different biological activities of Hypericum perforatum L. dry extract was tested in this study. Antioxidant activity was evaluated by four different assays. Antineurodegenerative activity was tested using acetylcholinesterase (AChE) and tyrosinase inhibitory activity assays. In all four antioxidant assays, concentration dependent manner was noticed in the activity of tested extract. The most active was the highest applied concentration $(500 \mu \mathrm{g} / \mathrm{ml})$. In DPPH test, extract applied in concentration of $200 \mu \mathrm{g} / \mathrm{ml}$ showed similar or higher radical scavenging activity compared to the concentration of 100 $\mu \mathrm{g} / \mathrm{ml}$ applied for standard substances BHA and BHT. The lowest antioxidant activity for the extract was detected in ABTS test. All applied concentrations of dry extract were significantly more potent than vitamin $C$ in $\beta$-carotene test. Moreover, the extract reached 40.31 and $45.56 \%$ of the inhibition in AChE and TYR assays, respectively. In both cases, the most active concentration of the extract was 200 $\mu \mathrm{g} / \mathrm{ml}$.
\end{abstract}

Key words: Hypericum perforatum, dry extract, biological activity

http://dx.doi.org/10.5937/leksir1737005S

\section{INTRODUCTION}

Hypericaceae includes 8 genera, with about 360 species, but only Hypericum perforatum (St. John's wort) is officially accepted for its positive pharmacological activities. It is included in European Pharmacopoeia 8.0 as well as in monographs of the European Medicines Agency, World Health Organization or European Scientific Association for Phytotherapy (Ph.Eur.8.0., 2014; EMA, 2009; WHO, 2002; ESCOP, 2003). Flowering aerial parts of St. John's wort have been commonly used in a form of tea, hydroalcoholic extracts or oil extracts, while standardized, dry hydroalcoholic extracts are used for the preparation of herbal products, i.e. capsule. Mainly, such solid preparations are recommended in the treatment of mild to moderate depressive episode (Butterweck and Schmidt, 2007). Moreover, St. John's wort has been used traditionally for the treatment of mild gastrointestinal complaints and stomach ulcer, or externally as oil extract for skin problems and wound healing agent (Miller et al., 1993; Tucakov, 1996). Chemical composition of H. perforatum is very complex and the several groups of compounds are considered as the active principles, i.e. naphthodianthrone derivatives hypericin and pseudohypericin, phloroglucinol derivatives hyperforin and adhyperforin, flavonoids and xanthones (Del Monte et al., 2015; Zdunić et al., 2017; WHO, 2002). Those compounds are connected with variety of biological activities such as antibacterial, antioxidant, antiviral, antiinlammatory (Šavikin et al., 2007; Zdunić et al., 2009; Saddiqe et al., 2010; Zdunić et al., 2017). Moreover, H. perforatum extract is proved to be an antidepressant for the treatment of depression with less side effects then synthetic drugs (Volz, 1997; Peron et al., 2013). Also, it is considered as neuroprotective agent that can prevent neurodegenerative pathologies by regulating neurotransmitter release in animal model, as well as by its antioxidant and antiinflammatory activity (Grundmann et al., 2010; Jungke et al., 2011; Klusa et al., 2001).

The aim of this work was to study antioxidant and antineurodegenerative properties of St. John's-wort dry extract obtained for commercial purposes in the Production Sector of the Institute for Medicinal Plant Research "Dr. Josif Pančićc".

\section{MATERIALS AND METHODS}

\section{Plant material}

St. John's-wort dry extract (4-6.5 : 1) was obtained from Production Sector of the Institute for Medicinal Plant Research "Dr. Josif Pančić". Extraction was done using 60\% EtOH. Extract was brown colored powder, with $5 \%$ percentage of moisture, $0.3 \mathrm{~mm}$ degree of fragmentation and it contained $0.14 \%$ of 
hypericin. The amount of hypericin was analyzed according to Ph. Eur. 8 and the amount corresponded to the requirement. Also, the amount of total phenolics was $58.11 \pm 0.94 \mathrm{mg}$ GAE/g (Singleton and Rossi, 1965) while the amount of total flavonoids was $28.55 \pm 0.65 \mathrm{mg} \mathrm{QE} / \mathrm{g}$ (Park et al., 1997).

\section{Evaluation of antioxidant activity}

\subsection{DPPH assay}

The scavenging activity of extract was evaluated using 2.2dyphenyl-1-picrylhydrazyl (DPPH) assay (Blois, 1958) with slight modifications. One hundred $\mu \mathrm{L}$ of extract solutions in methanol (concentrations of 100, 200 and $500 \mu \mathrm{g} / \mathrm{mL}$ ) and $900 \mu \mathrm{L}$ of methanolic solution of DPPH $(40 \mu \mathrm{g} / \mathrm{mL})$ were mixed. BHA, BHT and ascorbic acid in concentrations of 50 and $100 \mu \mathrm{g} / \mathrm{mL}$ were used as positive controls (standards). Methanol was used as a blank, while control was prepared to contain methanol instead of extract/standard. Absorbance of the reaction mixture was measured after 30 minutes in the dark at room temperature at $517 \mathrm{~nm}$. The decrease of absorption of $\mathrm{DPPH}$ radical at $517 \mathrm{~nm}$ was calculated using equation:

$$
\text { Inhibition of DPPH radical }(\%)=\frac{A C-A S}{A C} \times 100 \%
$$

, where AC is the absorbance of control (without test sample) and AS is the absorbance of the test sample at different concentrations.

All experimental measurements were carried out in triplicate and the results are expressed as average of three measurements \pm standard deviation.

\subsection{ABTS assay}

The scavenging activity of extract was evaluated using ABTS assay using procedure of Miller et al. (1993) with some modifications. Stock ABTS+ solution $(7 \mathrm{mM})$ was prepared $12-16$ hours before experiment in $2.46 \mathrm{mM}$ potassium-persulfate and stored in the dark at room temperature, and then diluted by distilled water to obtain an absorbance of working solution $0.700 \pm 0.020$ at $734 \mathrm{~nm}$. Extract solutions in methanol $(25 \mu \mathrm{L})$ in concentrations of 100,200 and $500 \mu \mathrm{g} / \mathrm{mL}$ were mixed with $1 \mathrm{~mL}$ of working ABTS+ solution and incubated for $30 \mathrm{~min}$ at $30^{\circ} \mathrm{C}$. The same procedure was applied for positive controls BHA, BHT and ascorbic acid in concentrations of 50 and 100 $\mu \mathrm{g} / \mathrm{mL}$. Absorbance was recorded at $734 \mathrm{~nm}$, and distilled water was used as blank, while control contained distilled water instead of sample. The decrease of ABTS radical absorption at $734 \mathrm{~nm}$ was calculated using equation:

$$
\text { Inhibition of ABTS radical }(\%)=\frac{A C-A S}{A C} \times 100 \%
$$

, where AC is the absorbance of control (without test sample) and AS is the absorbance of the test sample at different concentrations. All experimental measurements were carried out in triplicate and the results are expressed as average of three measurements \pm standard deviation.

\subsection{Ferric-reducing ability of plasma (FRAP) assay}

Ferric-reducing ability of plasma (FRAP) assay evaluates total antioxidant power of the sample using reduction of ferric tripyridyltriazine (Fe(III)-TPTZ) complex to the ferrous tripyridyltriazine (Fe(II)-TPTZ) by a test sample at low $\mathrm{pH}$. The FRAP assay was performed according to Benzie and Strain (1996) procedure with slight modifications. FRAP reagent was prepared freshly to contain sodium acetate buffer (300 $\mathrm{mmol} / \mathrm{L}$, pH 3.6), $10 \mathrm{mmol} / \mathrm{L} \mathrm{TPTZ} \mathrm{in} 40 \mathrm{mmol} / \mathrm{L} \mathrm{HCl}$ and $\mathrm{FeCl} 3 \times 6 \mathrm{H} 2 \mathrm{O}$ solution $(20 \mathrm{mmol} / \mathrm{L})$, i.e. in proportion 10:1:1 $(\mathrm{v} / \mathrm{v} / \mathrm{v})$, respectively. Working FRAP solution was warmed to $37^{\circ} \mathrm{C}$ prior to use. Extract solutions in methanol $(40 \mu \mathrm{L})$ in concentrations of 100, 200 and $500 \mu \mathrm{g} / \mathrm{mL}$ were added to 1200 $\mu \mathrm{L}$ of FRAP reagent and absorbance was recorded at $593 \mathrm{~nm}$ after 4 minutes. BHA, BHT and ascorbic acid (in concentrations of 50 and $100 \mu \mathrm{g} / \mathrm{mL}$ ) were used as standards. Distilled water was used as blank, while control was prepared to contain distilled water instead of extract. The same procedure was repeated for standard solution of FeSO4 x 7H2O (0.2-1.6 $\mathrm{mmol} / \mathrm{L}$ ) in order to construct calibration curve. FRAP values of sample was calculated from standard curve equation and expressed as $\mu \mathrm{mol} \mathrm{FeSO} 4 \times 7 \mathrm{H} 2 \mathrm{O} / \mathrm{g}$ dry extract. All experimental measurements were carried out in triplicate and the results are expressed as average of three measurements \pm standard deviation.

\section{4. $\beta$-carotene bleaching ( $(B-C B)$ assay}

$\beta$-carotene bleaching assay, designed to evaluate the capacity of the antioxidants to reduce the oxidative loss of $\beta$-carotene in a $\beta$-carotene linoleic acid emulsion, was performed according to slightly modified procedure of Dapkevicius et al. (1998). $\beta$-carotene (1 mg), linoleic acid $(50 \mu \mathrm{L})$ and Tween 40 (400 $\mathrm{mg}$ ) were dissolved in $2 \mathrm{~mL}$ of chloroform. Chloroform was removed using a rotary evaporator at $40^{\circ} \mathrm{C}$, and $200 \mathrm{~mL}$ of distilled water was added with vigorous shaking. The solutions of extract $(100,200$ and $500 \mu \mathrm{g} / \mathrm{mL})$ and positive controls BHA, BHT and ascorbic acid (50 and $100 \mu \mathrm{g} / \mathrm{mL}$ ) were prepared in methanol. Aliquots of $1000 \mu \mathrm{L}$ of the emulsion and $140 \mu \mathrm{L}$ of sample (extract/standard) were mixed. Distilled water was used as blank, while control contained distilled water instead of sample. The absorbances were measured immediately $(\mathrm{t}=0 \mathrm{~min})$ and after $2 \mathrm{~h}$ incubation $(\mathrm{t}=120 \mathrm{~min})$ at 490. The antioxidant activity of the sample was evaluated in terms of inhibition of $\beta$-carotene bleaching using the following equation:

$$
\% \text { Inhibition }=\frac{A 120-C 120}{C 0-C 120} \times 100 \%
$$

, where $\mathrm{A} 120$ and $\mathrm{C} 120$ are the absorbances measured in $\mathrm{t}=120$ minutes for sample and control, respectively, while $\mathrm{C} 0$ is absorbance of control in $\mathrm{t}=0 \mathrm{~min}$. All experimental measurements were carried out in triplicate and the results are expressed as average of three measurements \pm standard deviation.

\section{Evaluation of antineurodegenerative activities} 3.1. Acethylacholinesterase (AChE) inhibitory activity assay

AChE inhibitory activity assay was performed according to spectrophotometric method (Ellman et al., 1961) using 96-well plates as described befor (Orhan et al., 2012) with slight modifications. The AChE activity was measured by monitoring of increase of yellow color produced from tiocholine when it reacts with DTNB ion. The test reaction mixture $(S)$ was prepared by adding $140 \mu \mathrm{L}$ of sodium phosphate buffer $(0.1 \mathrm{M}$, $\mathrm{pH} 7.0), 20 \mu \mathrm{L}$ of DTNB, $20 \mu \mathrm{L}$ of extract-buffer solution containing 5\% DMSO (concentration of 100, 200 and $500 \mu \mathrm{g} / \mathrm{mL}$ ) and $20 \mu \mathrm{L}$ of AChE solution (5 units $/ \mathrm{mL}$ ). The mixture without extract was used as the control (C), while blank (B) did not contain AChE solution. The commercial anticholinesterase alkaloid-type of drug galanthamine was used as reference. After incubation $\left(15 \mathrm{~min}, 25^{\circ} \mathrm{C}\right)$, the reaction was initiated with the addition of $10 \mu \mathrm{L}$ of acetylthiocholine iodide and absorbance was measured at wavelength of $412 \mathrm{~nm}$ using Tecan Sunrise SN microplate reader equipped by XFluor4 software. Percentage of inhibition of AChE by sample was determined using the formula:

$$
\text { Inhibition of } \mathrm{AChE}(\%)=\frac{C-(S-B)}{C} \times 100 \%
$$

All experimental measurements were carried out in triplicate and the results are expressed as average of three measurements \pm standard deviation. 
Table 1. Antioxidant activity of St John's-wort dry extract

\begin{tabular}{lcrrrr}
\hline Sample & Concentration & $\begin{array}{r}\text { DPPH radical } \\
\text { scavengy } \\
\text { activity }\end{array}$ & $\begin{array}{r}\text { ABTS radical } \\
\text { scavengy activity } \\
\text { \% of inhibition }\end{array}$ & $\begin{array}{r}\text { FRAP activity } \\
\% \text { of inhibition }\end{array}$ & $\begin{array}{r}\beta \text {-carotene } \\
\text { bleaching activity }\end{array}$ \\
\hline SJW dry extract & 100 & $25.50 \pm 0.69 \mathrm{a}$ & $12.94 \pm 0.73 \mathrm{a}$ & $193.03 \pm 5.71 \mathrm{a}$ & $23.68 \pm 1.02 \mathrm{a}$ \\
& 200 & $44.69 \pm 0.39 \mathrm{~b}$ & $22.83 \pm 0.75 \mathrm{~b}$ & $361.98 \pm 3.80 \mathrm{~b}$ & $29.99 \pm 1.36 \mathrm{~b}$ \\
& 500 & $87.80 \pm 0.64 \mathrm{c}$ & $48.13 \pm 0.80 \mathrm{c}$ & $663.76 \pm 7.78 \mathrm{c}$ & $59.85 \pm 1.94 \mathrm{c}$ \\
\hline BHA & 50 & $28.21 \pm 0.60 \mathrm{~d}$ & $56.18 \pm 0.80 \mathrm{~d}$ & $231.22 \pm 4.71 \mathrm{a}$ & $50.79 \pm 2.76 \mathrm{~d}$ \\
& 100 & $43.33 \pm 0.87 \mathrm{~b}$ & $64.95 \pm 0.63 \mathrm{e}$ & $572.85 \pm 5.71 \mathrm{~d}$ & $57.70 \pm 1.91 \mathrm{c}$ \\
\hline BHT & 50 & $20.86 \pm 0.81 \mathrm{e}$ & $37.47 \pm 0.67 \mathrm{f}$ & $364.05 \pm 5.62 \mathrm{~b}$ & $48.74 \pm 1.79 \mathrm{~d}$ \\
& 100 & $34.31 \pm 0.43 \mathrm{f}$ & $55.11 \pm 0.44 \mathrm{~d}$ & $413.03 \pm 3.13 \mathrm{be}$ & $56.29 \pm 1.44 \mathrm{c}$ \\
\hline Vit C & 50 & $58.99 \pm 1.01 \mathrm{~g}$ & $35.14 \pm 0.58 \mathrm{~g}$ & $427.56 \pm 5.18 \mathrm{e}$ & $1.73 \pm 1.19 \mathrm{e}$ \\
& 100 & $91.65 \pm 0.21 \mathrm{~h}$ & $55.70 \pm 0.69 \mathrm{~d}$ & $576.17 \pm 7.61 \mathrm{~d}$ & $2.99 \pm 2.13 \mathrm{e}$ \\
\hline
\end{tabular}

a Values with the same letter $(\mathrm{a}-\mathrm{h})$ in each column showed no statistically significant difference $(\mathrm{P}<0.05)$; Statistical analysis was based on a one-way ANOVA and Bonferroni tests.

\subsection{Tyrosinase inhibitory activity assay}

Tyrosinase inhibitory activity assay was performed according to slightly modified spectrophotometric method of Masuda et al. (2005) using 96-well plates. Samples (extract and standard kojic acid) were dissolved in sodium phosphate buffer (0.1 M, pH 7.0) containing 5\% DMSO and phosphate buffer, respectively, in concentration of 100, 200 and $500 \mu \mathrm{g} / \mathrm{mL}$. The wells were designed as: A (containing $120 \mu \mathrm{L}$ of sodium buffer and $40 \mu \mathrm{L}$ of tyrosinase in the same buffer ( 46 units/L), B (containing only buffer), C (containing $80 \mu \mathrm{L}$ of buffer, $40 \mu \mathrm{L}$ of tyrosinase and $40 \mu \mathrm{L}$ of sample) and D (containing $120 \mu \mathrm{L}$ of buffer and $40 \mu \mathrm{L}$ of sample). After addition of $40 \mu \mathrm{L}$ of L-DOPA and incubation $\left(30 \mathrm{~min}, 25^{\circ} \mathrm{C}\right)$, absorbance was measured at $475 \mathrm{~nm}$ using Tecan Sunrise SN microplate reader equipped by XFluor4 software. Percentage of inhibition of tyrosinase was determined using the formula:

$$
\text { Inhibition of tyrosinase }(\%)=\frac{(A-B)-(C-D)}{(A-B)} \times 100 \%
$$

All experimental measurements were carried out in triplicate and the results are expressed as average of three measurements \pm standard deviation.

\section{Statistical analysis}

Results are presented as the mean value \pm standard deviation of three independent replicate experiments $(n=3)$. Statistical analysis was based on a one-way ANOVA test.Statistically significant effects were further analyzed and means were compared using Bonferroni test. A level of $\mathrm{P}<0.05$ was taken as statistically significant.

\section{RESULTS AND DISCUSSION}

\section{Evaluation of antioxidant activity}

Antioxidant activity of St. John's-wort dry extract was measured using four parallel tests and the results are presented in Table 1. Extract was tested in three concentrations (100, 200 and $500 \mu \mathrm{g} / \mathrm{ml}$ ), while standard substances BHA, BHT and ascorbic acids, in concentrations of 50 and $100 \mu \mathrm{g} / \mathrm{ml}$.

In all four assays, concentration dependent manner was noticed in the activity of tested extract. The most active was the highest applied concentration of $500 \mu \mathrm{g} / \mathrm{ml}$. In DPPH test, extract applied in concentration of $200 \mu \mathrm{g} / \mathrm{ml}$ showed similar or better radical scavenging activity compared to the concentration of $100 \mu \mathrm{g} / \mathrm{ml}$ applied for standard substances BHA and BHT . The lowest antioxidant activity for the extract was detected in ABTS test. Considering FRAP assay, only concentration of extract of $500 \mu \mathrm{g} / \mathrm{ml}$ was more active $(663.76 \mu \mathrm{mol}$ $\mathrm{Fe}(\mathrm{II}) / \mathrm{g}$ ) compared to the tested standard substances applied in concentration of $100 \mu \mathrm{g} / \mathrm{ml}$. Similar was in B-carotene test, but taking into account vitamin $C$, all applied concentrations of dry extract were significantly more potent than that standard substance in $100 \mu \mathrm{g} / \mathrm{ml}$.

Del Monte et al. (2015) reported higher DPPH radical scavenging activity of extracts they analyzed compared to our extract. Briefly, methanol and chloroform-methanol extracts they analyzed showed $73.07 \%$ and $77.23 \%$ of scavenging activity, respectively but, chloroform extract did not exhibit DPPH scavenging activity ( $\mathrm{IC}_{50}$ more than $\left.100 \mu \mathrm{l}\right)$. This difference is probably due to different solvents used in their study (methanol and chloroform-methanol)compared to 60\% EtOH in our. Moreover, Heydarian et al. (2017), showed that crude polysaccharides extracted from St John's-wort have DPPH and $\mathrm{OH}$ free radicals scavenging activity.

\subsection{Evaluation of antineurodegenerative activities}

Enzyme inhibition activity of St. John's-wort dry extract was tested against two enzymes, acetylcholinesterase (AChE) and tyrosinase (TYR), which are connected with development of the different neurodegenerative disorders. Loss of memory that occurs in Alzheimer's disease (AD) is characterized by reduced level of neurotransmitter acetylcholine. Consequently, cholinesterase inhibitors are proved to be effective in treating patients suffering of mild to moderately level of AD (Ahmed et al., 2013). Tyrosinase, a key enzyme in the synthesis of melanin, is also involved in the formation of neuromelanin which hyperproduction is associated with Parkinson's disease (PD) (Greggio et al., 2005). The current therapy for neurodegenerative diseases dominantly reduce progression of the disease but do not lead to complete cure. Also, such therapy is often accompanied by side effects. Plants or natural products which could prevent, slow down or cure various disorders, including neurodegenerative diseases are of great 
Table 2. Antineurodegenerative activity of St John's-wort dry extract

\begin{tabular}{|c|c|c|c|}
\hline & Concentration $(\mu \mathrm{g} / \mathrm{mL})$ & AChE inhibitory activity ${ }^{a}$ & Tyr inhibitory activity \\
\hline & & $\%$ of inhibition & $\%$ of inhibition \\
\hline \multirow[t]{3}{*}{ SJW dry extract } & 100 & $35.44 \pm 1.01 \mathrm{ab}$ & $41.08 \pm 4.60 \mathrm{a}$ \\
\hline & 200 & $40.31 \pm 4.73 a$ & $45.56 \pm 0.60 \mathrm{ab}$ \\
\hline & 500 & $31.32 \pm 2.22 b$ & $43.87 \pm 2.51 \mathrm{a}$ \\
\hline Galanthamine & 100 & $57.11 \pm 1.68 \mathrm{c}$ & - \\
\hline Kojic acid & 100 & - & $51.81 \pm 2.55 b$ \\
\hline
\end{tabular}

analysis was based on a one-way ANOVA and Bonferroni tests.

interest (Morzelle et al., 2016).

In our study, three concentrations (100, 200 and $500 \mu \mathrm{g} / \mathrm{ml})$ of St. John's-wort dry extract were tested in AChE and TYR inhibition assays and compared with the activity of $100 \mu \mathrm{g} / \mathrm{ml}$ reference drugs galanthamine and kojic acid, respectively $\mathrm{Ta}-$ ble 2). Both standard substances achieved an inhibition of over $50 \%$ at the concentration of $100 \mu \mathrm{g} / \mathrm{ml}$, while our extract reached 40.31 and $45.56 \%$ in AChE and TYR assays, respectively. In both cases, the most active was concentration of 200 $\mu \mathrm{g} / \mathrm{ml}$ of extract.

Although antineurodegenerative activities of $H$. perforatum extract were evaluated as weaker comparing to standards, it could be connected to the type of extragens applied for the production of extract.

Hernandez et al. (2010) tested water extracts of three Hypericum species from Portugal on AChE inhibitory activity and all species possessed activity but the lowest were detected for the extract of $H$. perforatum. Moreover, Cao et al. (2017) reported neuroprotective activity of $80 \%$ ethanolic $H$. perforatum extract against $\mathrm{AlCl} 3$-induced $\mathrm{AD}$ like pathology in rats. They concluded that beneficial effect of the extract could be due to its known antioxidant and anti-inflammatory activities.

\section{CONCLUSION}

In the present study, the results for antioxidant and antineurodegenerative activities of St. John's-wort dry extract are presented. The highest antioxidant activity has been noticed in DPPH test while the weakest was in ABTS test. All applied concentrations of dry extract were significantly more potent than vitamin $C$ in $\beta$-carotene test. Antineurodegenerative activities of $H$. perforatum extract were evaluated as moderate. Future research will be focused on extraction optimization aimed to enrich the extract with compounds that could contribute to AChE and TYR inhibitory activities.

\section{ACKNOWLEDGMENTS}

Acknowledgment. This work was supported by the Ministry of Education, Science and Technological Development of the Republic of Serbia, project number 46013, and 173029.

\section{REFERENCES}

Ahmed, F., Ghalib, R., Sasikala, P. and Mueen Ahmed, K. (2013). Cholinesterase inhibitors from botanicals, Pharmacognosy Reviews 7(14): 121.

Šavikin, K., Dobrić, S., Tadić, V. and Zdunić, G. (2007). Antiinflammatory activity of ethanol extracts ofHypericum perforatum L.,H. barbatum Jacq.,H. hirsutum L.,H. richeri
Vill. andH. androsaemum L. in rats, Phytotherapy Research 21(2): 176-180.

Benzie, I. F. and Strain, J. (1996). The Ferric Reducing Ability of Plasma (FRAP) as a Measure of "Antioxidant Power": The FRAP Assay, Analytical Biochemistry 239(1): 70-76.

Blois, M. S. (1958). Antioxidant Determinations by the Use of a Stable Free Radical, Nature 181(4617): 1199-1200.

Butterweck, V. and Schmidt, M. (2007). St. John's wort: Role of active compounds for its mechanism of action and efficacy, Wiener Medizinische Wochenschrift 157(13-14): 356-361.

Cao, Z., Wang, F., Xiu, C., Zhang, J. and Li, Y. (2017). Hypericum perforatum extract attenuates behavioral, biochemical, and neurochemical abnormalities in Aluminum chlorideinduced Alzheimer's disease rats, Biomedicine \& Pharmacotherapy 91: 931-937.

Dapkevicius, A., Venskutonis, R., van Beek, T. A. and Linssen, J. P. H. (1998). Antioxidant activity of extracts obtained by different isolation procedures from some aromatic herbs grown in Lithuania, Journal of the Science of Food and Agriculture 77(1): 140-146.

Del Monte, D., De Martino, L., Marandino, A., Fratianni, F., Nazzaro, F. and De Feo, V. (2015). Phenolic content, antimicrobial and antioxidant activities of Hypericum perfoliatum L., Industrial Crops and Products 74: 342-347.

EMA (2009). EMA/HMPC/101304/2008. Final: Community herbal monograph on Hypericum perforatum L., herba (Wellestablished use)., European Medicines Agency, London.

ESCOP (2003). ESCOP Monographs on the Medicinal Uses of Plant Drugs, Exeter: European Scientific Cooperative on Phytotherapy.

Greggio, E., Bergantino, E., Carter, D., Ahmad, R., Costin, G.-E., Hearing, V. J., Clarimon, J., Singleton, A., Eerola, J., Hellstrom, O., Tienari, P. J., Miller, D. W., Beilina, A., Bubacco, L. and Cookson, M. R. (2005). Tyrosinase exacerbates dopamine toxicity but is not genetically associated with Parkinson's disease, Journal of Neurochemistry 93(1): 246256.

Grundmann, O., Lv, Y., Kelber, O. and Butterweck, V. (2010). Mechanism of St. John's wort extract (STW3-VI) during chronic restraint stress is mediated by the interrelationship of the immune, oxidative defense, and neuroendocrine system, Neuropharmacology 58(4-5): 767-773. 
Hernandez, M. F., Falé, P. L., Araújo, M. E. M. and Serralheiro, M. L. M. (2010). Acetylcholinesterase inhibition and antioxidant activity of the water extracts of several Hypericum species, Food Chemistry 120(4): 1076-1082.

Heydarian, M., Jooyandeh, H., Nasehi, B. and Noshad, M. (2017). Characterization of Hypericum perforatum polysaccharides with antioxidant and antimicrobial activities: Optimization based statistical modeling, International Journal of Biological Macromolecules 104: 287-293.

Jungke, P., Ostrow, G., Li, J.-L., Norton, S., Nieber, K., Kelber, O. and Butterweck, V. (2011). Profiling of hypothalamic and hippocampal gene expression in chronically stressed rats treated with St. John's wort extract (STW 3-VI) and fluoxetine, Psychopharmacology 213(4): 757-772.

Klusa, V., Germane, S., Nöldner, M. and Chatterjee, S. S. (2001). Hypericum Extract and Hyperforin: Memory-Enhancing Properties in Rodents, Pharmacopsychiatry 34(Suppl1): 61-69.

Masuda, T., Yamashita, D., Takeda, Y. and Yonemori, S. (2005). Screening for Tyrosinase Inhibitors among Extracts of Seashore Plants and Identification of Potent Inhibitors from Garcinia subelliptica, Bioscience, Biotechnology, and Biochemistry 69(1): 197-201.

Miller, N. J., Rice-Evans, C., Davies, M. J., Gopinathan, V. and Milner, A. (1993). A Novel Method for Measuring Antioxidant Capacity and its Application to Monitoring the Antioxidant Status in Premature Neonates, Clinical Science 84(4): 407-412.

Morzelle, M. C., Salgado, J. M., Telles, M., Mourelle, D., Bachiega, P., Buck, H. S. and Viel, T. A. (2016). Neuroprotective Effects of Pomegranate Peel Extract after Chronic Infusion with Amyloid- $\beta$ Peptide in Mice, PLOS ONE 11(11): e0166123.

Orhan, I. E., Senol, F. S., Ozturk, N., Akaydin, G. and Sener, B. (2012). Profiling of in vitro neurobiological effects and phenolic acids of selected endemic Salvia species, Food Chemistry 132(3): 1360-1367.

Park, Y. K., Koo, M. H., Ikegaki, M. and Contado, J. 1. (1997). Comparison of the flavonoid aglycone contents of Apis mellifera propolis from various regions of Brazil., Arquivos de biologia e tecnologia 40(1): 97-106.

Peron, A. P., Mariucci, R. G., de Almeida, I. V., Düsman, E., Mantovani, M. S. and Vicentini, V. E. P. (2013). Evaluation of the cytotoxicity, mutagenicity and antimutagenicity of a natural antidepressant, Hypericum perforatum L. (St. John's wort), on vegetal and animal test systems, BMC Complementary and Alternative Medicine 13(1).

Ph.Eur.8.0. (2014). European Pharmacopoeia 8.0., Council of Europe, Strasbourg Cedex, France.

Saddiqe, Z., Naeem, I. and Maimoona, A. (2010). A review of the antibacterial activity of Hypericum perforatum L., Journal of Ethnopharmacology 131(3): 511-521.

Singleton, V. L. and Rossi, J. A. (1965). Colorimetry of Total Phenolics with Phosphomolybdic-Phosphotungstic Acid Reagents, American Journal of Enology and Viticulture 16(3): 144-158.

Tucakov, J. (1996). Healing by plants., Rad, Beograd.

Volz, H.-P. (1997). Controlled Clinical Trials of Hypericum Extracts in Depressed Patients - an Overview, Pharmacopsychiatry 30(S 2): 72-76.
WHO (2002). WHO Monographs on Selected Plants, Vol 2. Geneva World Health Organization, Geneva.

Zdunić, G., Gođevac, D., Šavikin, K. and Petrović, S. (2017). Comparative analysis of phenolic compounds in seven hypericum species and their antioxidant properties, Nat. Prod. Comm. [in press] .

Zdunić, G., Gođevac, D., Milenković, M., Vučićević, D. Šavikin, K., Menković, N. and Petrović, S. (2009). Evaluation of Hypericum perforatum oil extracts for an antiinflammatory and gastroprotective activity in rats, Phytotherapy Research 23(11): 1559-1564. 